\title{
Correction to: Polyphosphoinositide- Binding Domains: Insights from Peripheral Membrane and Lipid-Transfer Proteins
}

\author{
Joshua G. Pemberton and Tamas Balla
}

\section{Correction to:}

Chapter "Polyphosphoinositide-Binding Domains: Insights from Peripheral Membrane and Lipid-Transfer Proteins" in: J. G. Pemberton and T. Balla, Adv Exp Med Biol - Protein Reviews, https://doi.org/10.1007/5584_2018_288

This chapter was inadvertently published with an incorrect copyright holder. It has now been updated as

"This is a U.S. government work and not under copyright protection in the U.S.; foreign copyright protection may apply 2019”. 